\title{
AATTEEN VALLASSA. \\ Näkökohtia musiikki-instituution käsitteeseen
}

\section{Laitos vs. tapajärjestelmä}

Instituutio on väistämättä epämääräinen käsite, joka tieteenalasta riippuen saa erilaisia painotuksia ja rajauksia. Instituution ulkoisina tuntomerkkeinä on kuitenkin tavallisesti pidetty sitä, että sillä on tietty materiaalinen aparaatti (työvälineistö, mahdolliset rakennukset jne.), normijärjestelmä ja henkilöstö - ynnä toimintaa ylipäänsä ja henkilöstön sosiaalisaatiota tukeva ideologia. Instituutiolta edellytetään tiettyä pysyvyyttä, jatkuvuutta, jota takaamaan on syntynyt joukko kirjoitettuja ja kirjoittamattomia sääntöjä siitä miten instituution tulee toimia. (Ks. esim. Jones-Fowles 1984, 206-207; Liedman 1987, 181; Liedman -Olausson 1988, 10.) Sosiologian instituutiokäsite ei edellytä konkreettista laitosta (huolimatta ilmaisusta "instituutio eli sosiaalinen laitos"): instituutiot ovat vakiintuneita käyttäytymiskokonaisuuksia, joita säätelevät ao. yhteisön yleisesti hyväksymät ja sisäistämät normit ja roolit (Allardt 1983, 219-220; Eskola 1986, 181).

Sana instituutio näyttää kielessämme kuitenkin mieltyvän lähinnä johonkin konkreettiseen, jokseenkin selkeästi paikannettavissa, rajattavissa ja jäsennettävissä olevaan laitokseen tai organisaatioon. Ja vasta silloin kun jokin ilmiö jähmettyy tämänkaltaiseksi, sen katsotaan institutionaalistuvan. Nykysuomen sivistyssanakirjan selvästi kaksijakoisesta 
määritelmästä - "instituutio, tapajärjestelmä, oikeusjärjestys | (yhteiskunnallinen) laitos" (NSSK) - noteerataan siis etupäässä jälkipuolisko.

Erityisesti tämä näyttää koskevan sanaa musiikki-instituutio, jolla viitataan lähinnä orkestereihin, oppilaitoksiin, yhdistyksiin yms. laitoksiin. Nämä nähdään ikään kuin pelkkinä ulkoisina puitteina taiteelliselle toiminnalle, jonka varsinainen ydin ja lähtökohta on yksilö, taiteellisesti orientoitunut persoonallisuus. - Tällaista käsitystä ovat omiaan tukemaan ne lukemattomat musiikkibiografiat, joissa institutionaaliset interaktiot on jätetty liian vähälle huomiolle (vrt. Silbermann 1957, 164-165).

Paradoksaalista kyllä yksittäistä taiteilijaakin saatetaan puolileikillisesti kutsua "instituutioksi", mikäli hän on näkyvästi kohonnut kollegojensa yläpuolelle ja - mikä vielä tärkeämpää - arvostelun yläpuolelle, so. saavuttanut laajan ja kiistattomaksi kivettyneen arvostuksen. Vaikka tämä näyttääkin termin väärinkäytöltä, niin siinä painottuu käsitteen mielenkiintoisempi aspekti. "Instituutioksi" julistettu taiteilija ei eräiltä keskeisiltä ominaisuuksiltaan olekaan enää pelkkä omien lahjojensa ja ponnistelujensa hedelmä vaan yhteiskunnallinen tuotos, joka on syntynyt paljon uraputkeaan laajemmassa kontekstissa. Esim. Martti Talvela on painava nimi vielä kuoltuaankin ja painava nimi niillekin, jotka eivät ole koskaan kuulleet hänen laulavan.

Musiikki-instituutio on aina 'tapajärjestelmä', minkä lisäksi se voi olla tietty '(yhteiskunnallinen) laitos'. Molemmissa tapauksissa sillä on tietty tehtävä musiikkielämän piirissä. Tämän korostaminen ei ole triviaalia, sillä keskeisin tapa erottaa yksittäisiä musiikki-instituutioita toisistaan on niiden tehtävien kartoittaminen. Mikäli kaksi eri instituutiota pyrkii täyttämään saman tehtävän, niiden välisten erojen on löydyttävä keinoista - sikäli kuin meitä kiinnostavat todella sisäiset eivätkä vain ulkoiset erot. Tehtävä on tässä ajateltu instituution ulkopuolisesta kontekstista käsin määritellyksi. Instituution päämäärät ja keinot määritellään sen aatteessa, joka tietenkin pitää sisällään myös instituution oman käsityksen tehtävästään.

Musiikki-instituution konstituoivat siis sen a) tehtävä, b) aate, c) materiaalinen aparaatti ja d) henkilöstö. "Tapajärjestelmästä" puhuttaessa korostuvat kaksi ensimmäistä aspektia, "laitoksesta" puhuttaessa taas kaksi jälkimmäistä aspektia. Ne siis painottuvat eri tavoin mutta ovat silti kaikki välttämättömiä ehtoja instituutiolle, nähtiinpä tämä sitten ensisijaisesti konventionaalisten tapojen muodostamana systeeminä, konventionaalisena toimintana, laitoksena tai ihmisyhteisönä. 
Pelkkänä tapajärjestelmänäkään instituutio ei tietenkään ole olemassa ilman niitä ihmisiä, jotka noita tapoja noudattavat. Mutta "henkilöstön" asema laitoksen tai organisaation kaltaisessa instituutiossa on toki toinen. Jeffrey Wieand (1981) jakaakin instituutiot kahteen päätyyppiin, toiminta- ja henkilöinstituutioihin. Wieandin kategorioihin voi suhtautua kahdella tavalla.

Ensinnäkin voidaan jaotella kaikki musiikki-instituutiot kahteen, kautta linjan erikseen tarkasteltavaan ryhmään ja kieltäytyä edes ulottamasta instituutiokäsitteen alaa epämääräisiin tapauksiin. Keskittymällä pelkkiin toimintainstituutioihin voitaisiin tutkia esim. sitä peruskysymystä, mikä asema sosiaalisiksi käytänteiksi luokiteltavilla musiikkiinstituutioilla on yhteisön musiikillisessa kompetenssissa - jolla Gino Stefani tarkoittaa "kykyä tuottaa merkitystä musiikin avulla ja/tai sen piirissä" (ks. Stefani 1985, 12 ja 9). Pelkkiin henkilöinstituutioihin keskittymällä taas päädyttäisiin pian konkreettisten yhdistysten, instituuttien yms. tarkasteluun - josta on jo kosolti esimerkkejä olemassa. Sinänsä olisi hyödyllistä käydä läpi esim. erilaisten musiikkilaitosten historiikkeja tutkien niissä piilevää implisiittistä instituutioteoriaa.

Toinen mahdollisuus on ottaa Wieandin termit pelkiksi lähtökohdiksi sitoutumatta hänen lakonisiin määritelmiinsä. Tiukka jaottelu jää tällöin tekemättä mutta pysyy ikään kuin varomattomien yleistysten kontrollina, kun erilaisia, ylipäänsä musiikki-instituutioihin liittyviä näkökohtia marssitetaan esiin, kun avataan monia ovia astumatta kaikista sisään. Tästä on kyse seuraavassa.

\section{Toiminta- vs. henkilöinstituutio}

Wieandin jaottelun lähtökohta on tämä:

"A[ction]-institution is an action-type whose tokens are particular performances of that type of action. [--] P[erson]-institutions function as quasi-person or agents: they perform actions and may be held responsible for them."

Toimintainstituutiossa ei ole kyse mistä tahansa sosiaalisesta käytänteestä vaan sellaisesta sääntöjen hallitsemasta, konventionaalisesta aktista kuten esim. lupaaminen (jonka sääntönä on lupauksen rikkomisen kielto). Henkilöinstituutiossa ei ole kyse mistä tahansa sattumalta yhdenmukaisesti toimivasta ihmisryhmästä vaan tavalla tai toisella organisoituneesta kokonaisuudesta kuten esim. katolinen kirkko. "Kun henki- 
löinstituution jäsenet toimivat instituutionsa puolesta, instituutio toimii heidän kauttaan ja jäsenten toimintaa voidaan kuvata sekä tiettyjen ihmisten että instituution toimintana." Wieandin mukaan henkilöinstituutiot suorittavat periaatteessa samanlaisia toimintoja kuin yksittäiset henkilöt, ne voivat esim. antaa julistuksen - ja julistuksen antamisessa puolestaan on kyse toimintainstituutiosta. (Wieand 1981, 409-410)

Useimmat musiikki-instituutiot ovat henkilöinstituutioita. Tämä ei estä sitä, että niiden puitteissa esiintyy sellaisia erityiskäytänteitä, joita voisi kenties Wieandinkin näkökulmasta pitää toimintainstituutioina: esim. frakin käyttö orkesterissa. Nämä eivät nyt kuitenkaan ole tässä mielenkiinnon kohteena. Ongelma on siinä, voidaanko niitä - laajempiakin - musiikki-instituutioita, jotka eivät selvästi ole laitoksia tai organisaatioita vaan pikemmin tapajärjestelmiä, ilman muuta pitää toimintainstituutioina. Toinen ongelma on siinä, eikö jotakin henkilöinstituutiota voisi pitää ylipäätäänkään instituutiona, mikäli tuntuu oudolta sanoa että joku - kuten Wieand sanoo - "toimii sen puolesta" ('to act on behalf').

Edellä totesin, että musiikki-instituutio on aina tapajärjestelmä minkä lisäksi se voi olla tietty laitos. Tässä piilee käsittääkseni myös toiminta- ja henkilöinstituution välinen ero: edellinen on sidoksissa tietynlaiseen, jälkimmäinen suorastaan tiettyyn materiaaliseen aparaattiin ja henkilöstöön. Esim. konsertti-instituutio on toimintainstituutio, Helsingin kaupunginorkesteri taas henkilöinstituutio. Tehtävältään ja aatteeltaan ne voivat muistuttaa toisiaan, mutta materiaalinen aparaatti ja henkilöstö kiinnittävät HKO:n aikaan ja paikkaan.

Toiminta- ja henkilöinstituution ero ei kuitenkaan ole kaikissa tapauksissa selvä; joissakin tapauksissa se saattaa näyttää pelkästään suhteelliselta eikä periaatteelliselta. Mitä tiukemmin jokin laaja toimintainstituutio - esim. musiikkikritiikki - rajataan historiallisesti ja maantieteellisesti, sitä enemmän se alkaa näyttää henkilöinstituutiolta. Kun instituutio - esim. nykymusiikki - on tiettyyn ajankohtaan sidottu, se näyttää väistämättä olevan henkilöinstituutio, niin laaja ja epämääräinen kuin sen edellyttämä henkilöstö onkin. Tästä ei tietenkään saa vetää sellaista johtopäätöstä, että toimintainstituutio olisi ylihistoriallinen.

Musiikkikritiikin ja nykymusiikin välillä on kuitenkin muuan tärkeä periaatteellinen ero. Kriitikoista ei, vaikka instituution koko henkilöstö nimettäisiin, synny organisoitunutta yhteisöä vaan vain joukko toisistaan erillään työskenteleviä yksilöitä. Näiden ei tarvitse toimia minkään muun musiikki-instituution välityksellä. Suomen Arvostelijain Liitto on tietenkin henkilöinstituutio, mutta musiikkikriitikon varsinainen työ ei 
tapahdu sen piirissä eikä millään tavalla edes edellytä sen olemassaoloa. Nykymusiikki - voidakseen ylipäätään olla instituutio - edellyttää toimiakseen koko joukon henkilöinstituutioita, jotka ovat valmiita tukemaan nykymusiikin aatetta ja tehtävää ja joiden välillä on monipuolista yhteistoimintaa. Nykymusiikki on siis instituutioiden instituutio, ja tällaisena se on selvästi kiinteämpi kuin esim. konsertti-instituutio, joka sekin edellyttää erilaisia henkilöinstituutioita kyetäkseen toimimaan mutta joka ei kuitenkaan ole näiden henkilöinstituutioiden muodostama kokonaisuus.

Joitakin lisäesimerkkejä. Konsertti-instituutioon verrattava laajahko toimintainstituutio olisi esim. laulukilpailuinstituutio, jonka yksittäisiä ylläpitäjiä (esim. Lappeenrannan laulukilpailut) olisi pidettävä henkilöinstituutioina. Esimerkkejä henkilöinstituutioista on helpompi löytää. Nykymusiikkiin verrattavia instituutioiden instituutioita ovat vakava ja kevyt musiikki sekä kansanmusiikki, kun taas ooppera(musiiki)n ja varsinkin sinfonia(musiiki)n instituutioluonne on jo tulkinnanvaraisempi. Näyttää kuitenkin siltä, että oopperan ja sinfonian kaltaisten kategorioiden kohdalla jo niiden nimi on oire institutionaalisuudesta. Eivätkö tekijät halua päästä osallisiksi juuri instituution myötä tarjoutuvista eduista, kun he antavat teoksilleen - vastoin niiden faktisia lajiominaisuuksia - sellaisia nimiä kuin Jokiooppera, Savottaooppera, Evakkoooppera jne?

Joka tapauksessa yksi koko kirjoitukseni pääajatuksia on se, että tällaisiakin musiikin kategorioita kannattaisi tarkastella myös institutionaalisen eikä pelkästään musiikillisen analyysin avulla. Institutionaalisen analyysin ei siis tarvitse pysähtyä "instititutionaaliseksi" kutsuttuun (ks. Mueller 1963) musiikkiin, so. siihen jonka käyttö ja merkitykset ovat sidoksissa kirkkoon, valtioon tms. sosiaaliseen instituutioon. Ajatus on sopusoinnussa sen musiikkisosiologisen näkemyksen kanssa, jonka mukaan yhteiskunnallisten tekijöiden vaikutusta musiikinhistoriaan on jäljitettävä musiikin muodoista sellaisina kun nämä ilmenevät lajissa (Gattung) ja epookin tyylissä; musiikin "sisältö" tai yksittäiset teokset eivät ole tässä suhteessa relevantteja (vrt. Wiora 1962; Kneif 1966, 8789; Kneif 1975, 99-100).

Tästä ei kuitenkaan pidä vetää niin yksinkertaista johtopäätöstä, että yhteiskunnallisen kehityksen ja lajihistorian väliltä löytyisi suoria paralleeleja (varottavia esimerkkejä tällaisista tutkimuksista kyllä riittää). Musiikki-instituutiot yksinkertaisesti vain muodostuvat siihen kohtaan, jossa sävelteokset kohtaavat yhteiskunnan ja yhteiskunta sävelteokset tai: vasta instituutiot tekevät tämän kohtaamisen ylipäätään mahdolli- 
seksi. Yhteiskunnalliset tekijät eivät ole musiikki-instituution ulkopuolisia vaan sisäisiä voimia.

\section{Rajat ja relationaalisuus}

Jos konsertti-instituutio on toimintainstituutio, niin onko enää järkevää pitää frakin käyttöä toimintainstituutiona? En näe siihen mitään periaatteellista estettä. Frakin käyttö on sosiaalinen käytänne, jonka sääntöjä noudatetaan paitsi erilaisten musiikki-instituutioiden myös muiden instituutioiden (esim. yliopisto) piirissä. Niin Helsingin kaupunginorkesterin kuin konsertti-instituution puitteissa se näyttää suhteellisen periferiseltä joskaan ei täysin merkityksettömältä instituutiolta. Joka tapauksessa sekin on instituutio, riippumatta siitä halutaanko Helsingin kaupunginorkesteria tai konserttielämää koskevassa instituutiohistoriassa puhua instituutiosta instituutiossa.

Instituutioiden sisäkkäisyys ja se, että jokin instituutio näyttää leikkaavan useita muita, kuuluvat siis asian luonteeseen instituutioiden konfiguraatioissa - oli sitten kyse toiminta- tai henkilöinstituutioista. Niin Helsingin kaupunginorkesteri kuin konsertti-instuutio ovat riippuvaisia monista sekä spesifisti musiikillisia että yleisesti yhteiskunnallisia funktioita palvelevista instituutioista. Koska näistä on tärkeätä puhua nimenomaan instituutioina, tätä termiä on paras käyttää säästeliäästi luonnehdittaessa instituution sisäisiä sosiaalisia käytänteitä - vaikka nämä olisivatkin toimintainstituutioita.

Sen sijaan henkilöinstituutioita, vaikka ne jäisivätkin tutkimuksen kohteena olevan laajemman instituution sisälle, on tarkasteltava edelleen nimenomaan instituutioina (esim. Korvat auki! -yhdistys nykymusiikkiinstituutiossa). Näin jo siitäkin syystä, että harvoin pienenkään henkilöinstituution voi katsoa jäävän kokonaisuudessaan toisen instituution sisälle ilman että se samalla jossain suhteessa olennaisesti kuuluisi vielä kolmanteen tai useampiin instituutioihin.

Usein vasta mahdollisimman laajasta näkökulmasta katsoen alkavat instituutioiden ratkaisevat erot ja niiden raja tulla näkyviin. Vakavan ja kevyen musiikin välinen syvä, kautta yhteiskunnan kulkeva kuilu paljastuu, kun tarkastellaan kummankin koulutusta, tuotantoa (säveltämisestä äänilevyihin), jakelua ja vastaanottoa (kuulijoista tiedotusvälineisiin) ja näiden taustalla olevaa aatemaailmaa (vrt. Heiniö 1985a). Kyse on nimenomaan institutionaalisista eroista, mikä tekee ymmärrettäväksi, että vakavan ja kevyen välisellä 'demilitarisoidulla' vyöhykkeellä pysyttelevä 
taiteilija jää helposti vaille tukiryhmiä. Kevyen musiikin edustajat käyttävät termejä "ns. vakava ja ns. kevyt musiikki", mikä tuskin lienee sokeutta näiden instituutioiden olemassaololle vaan lähinnä pelkkiin sanoihin kohdistuvaa kritiikkiä. (Ylipäänsä nimittelyn nyanssitkin kertovat jo paljon instituutioiden välisistä ideologisista suhteista: esim. eräät länsisaksalaiset lehdet eivät ole kirjoittaneet itänaapurin nimeä muotoon DDR vaan "DDR".)

Edellä oleva esimerkki tuo esille piirteen, joka on tietynlaisten instituutioiden kannalta keskeinen, nimittäin relationaalisuuden. Tämä näkyy usein jo instituution nimikkeessä. Vakavan musiikin käsite pitää sisällään sen aspektin, että se $e i$ ole kevyttä musiikkia - ja päinvastoin. $\mathrm{Ne}$ voidaan siis määritellä vain suhteessa toisiinsa. Vastaavasti nykymusiikki pyrkii erottautumaan muusta länsimaisesta taidemusiikista, sekä vanhasta että siitä uudesta jota se pitää vanhanaikaisena. Instituution seinä saadaan näkyviin siten, että katsotaan mitä seinän takana on. Tämä seuraa tietenkin jo siitä itsestäänselvyydestä, että yhteiskunnallisessa kilpailussa harva henkilöinstituutio toimii jonkin puolesta ilman, että se samalla toimisi jotakin vastaan.

\section{"Taidemaailma"}

Instituution käsite on keskeinen monissa yleisissä taideteorioissa, joista tunnetuimpia lienee George Dickien hahmotelma taidemaailmasta. Itse termi on alunperin lähtöisin Arthur Danton ajatuksesta: "To see something as art requiers something the eye cannot descry - an atmosphere of artistic theory, a knowledge of history of art: an artworld." Ensisilmäyksellä Dickien lähtökohta näyttää siltä mitä edellä alleviivasin: instituutio on vakiintunut käytänne, sen ei tarvitse olla kiinteä yhteisö tai korporaatio (Dickie 1974, 29-31). Dickien varsinaiseen tavoitteeseen so. taideteoksen määrittelyyn sen institutionaalisuudesta käsin - ei seuraavassa ole tarpeen ottaa kantaa. Sen sijaan Dickie teksteissä nousee esiin kolme käsitettä joista lähtien tarkastelua voi jatkaa: kehykset, säännöt ja roolit.

Dickie (seuraavien sitaattien lähteenä on Dickie 1987, 122-126) luonnehtii sitä kontekstia, jossa taide syntyy ja elää, "kulttuuritavaksi, instituutioksi, joka koostuu määrätyin vakiintunein tavoin toimivien henkilöiden rooleista". Täten taideteos on paitsi artefakti myös sellainen "jolle joku tai jotkut tietyn sosiaalisen instituution (taidemaailman) puolesta toimivat henkilöt ovat suoneet aseman potentiaalisen arvostuksen 
kohteena". "Taidemaailmalla" Dickie ei ole halunnut viitata joihinkin päätösvaltaisiin ryhmiin vaan siihen "eriytyneiden roolien kokonaisuuteen, jonka täytyy toimia, jotta taiteen tekeminen olisi mahdollista" ja sellaiseen laajaan toimintaan, joka on "vailla tarkkoja sääntöjä". Keskeisimpien roolien - taiteilijan ja yleisön - ohella taidemaailmaan kuuluu vielä erilaisia organisaattorien ja tiedottajien rooleja.

Vaikka taidemaailman sisällä on organisoituneita kokonaisuuksia kuten museot ja taiteilijoiden ammattikunnat, niin Dickien mukaan se ei itse ole kaavamaisesti organisoitu kokonaisuus. Taidemaailma sinänsä ei ole luomassa taidetta eikä hyväksymässä tiettyjä tuotteita taiteeksi, vaan se tarjoaa pelkästään "kehyksen" taiteen tekemiselle. Tämä "historiallisesti kehittynyt kulttuuri-instituutio (käytäntö)" pitää sitten sisällään "pienempiä taidemaailmasysteemejä": eri taiteenalat.

Dickien taideteoriaa on runsaasti arvosteltu (ks. Haapala 1989, 25 36) mm. siitä, että se sisältää kehäpäätelmiä (taideteos määrittää taidemaailmaa ja päinvastoin). Jeffrey Wieandin mukaan hän yrittää väittää toimintainstituutioksi sitä mikä hänen luonnehdintojensa perusteella olisi kuitenkin selvä henkilöinstituutio. Mutta koska henkilöinstituutiossa jäsenen pitää voida toimia instituutionsa puolesta tilivelvollisena muille jäsenille, taidemaailma ei ole edes henkilöinstituutio. (Wieand 1981, 412-413.) Edelleen on katsottu, että institutionaalinen teoria ei ole edes taiteen vaan pikemmin taidepolitiikan, so. taiteen statuksen ja legitimoinnin teoria ja tällaisenakin vain $a d$ hoc -käyttöön riittävä (Wartofsky 1980). - Itse asiassa juuri nykyistä taidepolitiikkaa valaisevaa teoriaa kaivattaisiinkiin, kun musiikki-instituutioita lähdetään tarkastelemaan. Mutta Dickien eväillä ei järin pitkälle pääse. (Tutustumisen arvoinen musiikkipoliittinen monografia - tosin vailla teoreettista viitekehystä on Lindblom 1981.)

Dickien taidemaailma-abstraktio näyttää melko ohuelta tai vähintäänkin hänen kiikarinsa pitäisi kääntää oikeapäin, jotta sillä voitaisiin nähdä sen kokoisia musiikki-instituutioita joita olen edellä nostanut esiin. Tuntuu oudolta korostaa sitä, että taidemaailman toiminta on "vailla tarkkoja sääntöjä". Kyse kai lienee lähinnä siitä, miten yksityiskohtaisella tasolla taidemaailmaa tarkastellaan. Sillä tasolla, jolla teorioille voidaan antaa empiiristä evidenssiä, täytyy sääntöjen - ja jopa suhteellisen tarkkojen sääntöjen - tulla näkyviin. Erityisen omituinen on Dickien ajatus siitä, että taidemaailma ei "kehyksen" ominaisuudessaan olisi se, joka hyväksyy jonkin teoksen taiteeksi. Mikäli tämä pitää paikkansa, taidemaailma ei todellakaan voi olla instituutio ainakaan siinä 
merkityksessä, mikä sanalle tässä annetaan, eikä Dickien teoria ole edes taidepolitiikan teoria.

\section{"Kehykset" vs. toiminta}

Taidemaailman "kehykset" voidaan nähdä esteettisenä sääntöjärjestelmänä, joka ratkaisee mm. mikä vielä on taidetta (vrt. Säätelä 1986, 24). Luonnehtiessaan taidemaailmaa taiteen tekemisen kehyksiksi Dickie implikoi kuitenkin sanalle väljemmänkin merkityksen, johon tartun hetkeksi.

Ajassa ja paikassa instituutiot ovat toki jotain paljon laajempaa kuin se aktuaalinen toiminta, jota niiden puitteissa tapahtuu. Tämä on omiaan korostamaan niiden luonnetta toiminnan kehyksensä ja mahdollistaa niiden rakenteiden hahmottamisen - jos ei muuten niin ainakin heuristisina malleina. Mielikuva musiikki-instituutiosta jonkinlaisena aktiviteettien astiana voi kyllä olla harhaanjohtavakin. Kehykset sulautuvat toimintaan ilman rajaa, ne ovat kuin hitaampia kontrapunkteja siinä tiheässä polyfoniassa, jonka erilaisten historiallis-yhteiskunnallisten vaiheiden kautta vaeltava instituutio muodostaa.

Saattaisi olla jopa hedelmällisempää nähdä kehyksetkin - aina materiaalista aparaattia myöten - toimintana kuin leimata osaakaan toiminnasta pelkiksi kehyksiksi; toiminta mahdollistaa "kehykset" eikä päinvastoin. Tarkasteltaisiin esim. Finlandia-taloa konsertti-instituution toiminnan osana - eikä vain anonyymina rakennuksena, jota instituution on silloin tällöin käytettävä. Tätä ei estä se, että Finlandia-talo lisäksi on itsessään instituutio - ja juuri instituutioiden väliset ristiriidat paljastuvat setvittäessä niitä tunnettuja ongelmia jotka liittyvät talon käyttöön konserttisalina.

Kehysten näkeminen toimintana - tai muodon näkeminen sisältönä tuntuisi luontevalta erityisesti dynaamisten ja suhteellisen pienten instituutioiden kohdalla, joissa tapahtuu nopeita muutoksia ja joiden olemassaolo ei ole kiinni tietystä materiaalisesta aparaatista (esim. Korvat auki! -yhdistys). Tällaiset instituutiot ovat kyllä sitten varsin herkkiä henkilöstön vaihdoksille. Mikäli instituutio on - kuten nykymusiikki - ottanut jatkuvan uudistumisen tavoitteekseen, keskeinen osa sen toiminnasta kohdistuu pakostakin sen kehyksien pohdiskeluun ja muokkaukseen. Tällöin joudutaan tietenkin kysymään, mikä siinä ylipäänsä on se suhteellisen pysyvä momentti, jonka perusteella sitä voi pitää instituutiona. 


\section{Ontologinen status; säännöt ja uskomukset}

Vähintä mitä instituutiosta voidaan sanoa, on se, että se ainakin on yksi adekvaatti näkökulma, josta monia musiikkielämän ilmiöitä kannattaa tarkastella. Toinen kysymys sitten on, ovatko instituutiot "todella" olemassa. Molemmat huomautukset koskevat lähinnä toimintainstituutioita (esim. konsertti-instituutio) eivätkä niinkään henkilöinstituutioita (esim. Helsingin kaupunginorkesteri). Itse asiassa juuri se, tuleeko instituution ontologisesta statuksesta ongelma vai ei, vihjaa jo siihen, onko kyseessä toiminta- vai henkilöinstituutio. Konsertti-instituutio on abstraktio monien henkilöinstituutioiden toiminnasta, se on ulkopuolisen tarkkailijan luoma "eettinen" käsite, ja voidaan aiheellisesti kysyä, onko se vain pelkkä ajatusmalli. Nykymusiikki taas on selvästi (ala)kulttuurinsisäinen, "eeminen" käsite, joka on määritelty instituution aatteessa. Tämä aate- ynnä monet organisaatio- ja kommunikaatiositeet yhdistävät joukon henkilöinstituutioita yhdeksi suureksi henkilöinstituutioksi, nykymusiikiksi.

Huomattakoon kuitenkin, että Eerik Lagerspetz, jonka ajatuksista seuraavassa lähden, ei tee jakoa toiminta- ja henkilöinstituutioihin. Lagerspetzin $(1989,10)$ mukaan niin tutkijat kuin maallikot lähtevät yleensä seuraavista neljästä intuitiivisesta käsityksestä:

(1) institutionaaliset termit viittaavaat todella olemassa oleviin seikkoihin.

(2) yritettäessä selittää instituutioiden ominaisuuksia ja toimintaa emme kuitenkaan viime kädessä löydä muuta kuin yksittäisiä ihmisiä, heidän ominaisuuksiaan, uskomuksiaan, aktioitaan ja interaktioitaan.

(3) instituutioiden ominaisuuksia ja toimintaa koskevat väitteet eivät silti ole väitteitä yksittäisten ihmisten mielentiloista tai fyysistä liikkeistä vaan niillä on jotain tekemistä normien ja sääntöjen kanssa.

(4) on mahdollista puhua instituutioista sitoutumatta johonkin normi- tai sääntöjärjestelmään.

Tässä yhteydesșä ei ole tarpeen mennä syvemmälle siihen ontologiseen problematiikkaan, jota Lagerspetz tarkastelee ottaen lähtökohdakseen sen, että ensi silmäyksellä yhtäältä (1) ja (2), toisaalta (3) ja (4) eivät sovi yhteen. Lagerspetzinkin mukaan "sopivasti tulkittuna" nämä käsitykset ovat oikeita ja keskenään yhteensopivia. Hyväksyn myös käsitykset (1) ja (3) annettuina puuttumatta niihin suunnattuun nominalistiseen kritiikkiin. 
John Searle erottaa (luonnontieteellisin menetelmin tutkittavat) "raa'at tosiasiat" "institutionaalisista". Jälkimmäiset ovat tosiasioita nekin, mutta ne edellyttävät tiettyjen inhimillisten instituutioiden olemassaoloa - ja nämä instituutiot ovat konstitutiivisia sääntöjärjestelmiä: "Every institutional fact is underlain by (a system of) rule(s) of the form 'X counts as Y in context C'." (Searle 1974, 51-52). Konstitutiivisista säännöistä, jotka siis määrittelevät jonkin joksikin, Searle erottaa regulatiiviset säännöt, jotka ohjaavat kehottamalla tai kieltämällä. Tätä Lagerspetz täydentää edellyttämällä, että on olemassa lisäksi sääntö, jonka mukaan jokin on sääntö - ja se sääntö ei enää perustu sääntöön vaan konventioon (Lagerspetz 1989, 22-23).

Jotta jokaista sääntöä ei jouduttaisi selittämään sen takana piilevällä säännöllä loputtomiin, Lagerspetz esittää:

"There are things which exist and facts which hold if and only if the relevant indivuals believe that they exist or hold and act according to these beliefs. What we call institutions and institutional facts fall under this description."

Ei riitä, että yhteisön jäsenet sattuvat uskomaan tietyllä tavalla, vaan lisäksi heidän täytyy tietää toistensa uskovan tällä tavalla. Sitäpaitsi tuo uskomus pitää olla nimenomaan "relevanteilla" yksilöillä ja sen pitää olla suhteessa toimintaan, vaikuttaa siihen tavalla tai toisella. Tällaista näkemystä Lagerspetz kutsuu "konventionalismiksi". (Mts. 14-15)

Musiikki-instituutiotakin voidaan tarkastella sarjana uskomuksia, jotka ovat yhteisiä tietyn, musiikkiin liittyvän päämäärän hyväksi toimiville ihmisille. Jokaisella musiikki-instituutiolla on sekä eksplisiittisiä sääntöjä - siis sääntöjä sanan arkimerkityksessä - että implisiittisiä sääntöjä, jotka piilevät uskomusten järjestelmässä tämän normatiivisena aspektina. Konstitutiivisilla säännöillään instituutio itse määrittelee luonteensa, tavoitteensa sekä jäsen- tai henkilöstökriteerinsä ("relevantit" yksilöt). Nämä näkökohdat ovat sopusoinnussa jo Émile Durkheimin aikoinaan esittämän väljän instituutiomääritelmän kanssa, jonka mukaan instituutiona voidaan pitää "kaikkia yhteisön instituutioimia uskomuksia ja käyttäytymistapoja". (Tästähän Durkheim eteni sitten määrittelemään koko sosiologian "instituutioiden, niiden synnyn ja funktioiden tieteeksi".) (Durkheim 1977, 28-29) 


\section{Roolit}

Dickien teoriassa esiintyvä ajatus instituutiosta "eriytyneiden roolien kokonaisuutena" on huomionarvoinen mutta kaipaa spesifioimista - olletikin kun englannin sana rôle voi merkitä 'roolin' lisäksi yksinkertaisesti 'tehtävää'. Kullakin roolilla on toiminnan kokonaisuudessa oma erityinen kvaliteettinsa ja oma korvaamaton funktionsa. Mutta eri rooleilla on lisäksi erilainen merkitys niille yksilöille ja ryhmille, jotka näihin rooleihin astuvat: kaikkiin rooleihin ei sijoiteta yhtäläistä intressiä ja volyymiä, kaikkia rooleja edustaviin ryhmiin ei samaistuta yhtä totaalisesti.

Selvin ero on musiikin vastaanottajien ja sen tekijöiden välillä. Kuuluminen konserttiyleisöön merkitsee tietynlaista ryhmäkäyttäytymistä, mutta varsinaiseksi viiteryhmäksi se ei jäsenilleen muodostu. Konserttiyleisö on anonyymi ryhmä, kun taas instituution pitänee voida periaatteessa yksilöidä roolin kantajat. Niinpä yleisö on pikemminkin pelkkä funktio kuin rooli sanan sosiologisessa merkityksessä. Yleisö on instituution kannalta välttämätön, mutta samalla se on instituution ulkopuolella: se kykenee antamaan vain kategorista, kvantitatiivista palautetta (hyväksyy/hylkää), joka sekään ei yleensä vaikuta ennen kuin pidemmällä tähtäimellä.

Voidaan tietenkin sanoa, että yleisöllä on kyllä rooli mutta se ei ole tämän kummempi. - Auki jää kuitenkin edelleen se kysymys, sijoittuuko tämä rooli yleiseen toimintainstituutioon (esim. konsertti-instituutio), erityiseen henkilöinstituutioon (esim. Helsingin kaupunginorkesteri) vai molempiin. Todelliset roolit eivät toki rajoitu henkilöinstituutioon. (Ne esimerkit, joita Wieand luettelee toimintainstituutioista - lupauksen antaminen, avioliitto jne. - osoittavat, että niistäkin on helppo erottaa rooleja: lupauksen antaja/vastaanottaja, mies/vaimo jne.)

Edelliset yleisöä koskevat huomiot liittyvät länsimaisen taidemusiikin konsertti-instituutioon. Ne eivät päde sellaiseen kulttuuriin tai alakulttuuriin jossa jokainen on potentiaalinen muusikko, eikä liioin muihin musisoimistilanteisiin, joissa kvalitatiivinen palaute seuraa lähes reaaliajassa ja muodostaa siten eräänlaisen "dialogin" itse esityksen kanssa. Jonkinlainen erikoistapaus taidemusiikin puolelta olisi ehkä sellainen (ei niinkään harvinainen) nykymusiikkikonsertti, jossa säveltäjät esityttävät teoksiaan kollegoilleen ym. alan ammattilaisille. Tuskin tällöinkään tuntuisi kovin luontevalta sanoa, että kollegat ym. ammattilaiset ovat yleisön roolissa. (Kadunmies ainakin sanoisi, ettei konsertissa ole yleisöä lainkaan.) 
Yleisön rooli on ohentunut funktioksi siis sellaisessa musiikkikulttuurissa, jossa tekijäpuoli on ammatillisesti pitkälle erikoistunut. Länsimaisessa taidemusiikissa korostuvat nimenomaan ammatilliset roolit ( $\mathrm{ja}$ ammattiin liittyvät identiteetit) spesifisine arvoineen ja normeineen, joiden tarkasteluun (työn)sosiologia ja antropologia tarjoavat lähtökohtia (ks. esim. Allardt 1983, 58-77; Asp-Peltonen 1980, 54-68; Eskola 1986, 169-186; Robbins 1973; Douglas 1987, 55-67). Rooliin tiivistyvät ne instituution konstitutiiviset ja regulatiiviset säännöt, jotka koskevat tietyn tehtävän hoitamistapaa.

Erikoistumisesta huolimatta musiikkielämän ammattilaisten toiminta on niin monitahoista, että ensinnäkin samat ihmiset työskentelevät eri instituutioiden piirissä kuljettaen näkemyksiään instituutiosta toiseen ja toiseksi tehtävät, ammatit, tittelit ja roolit helposti vyyhtiytyvät sekä käytännöllisessä että käsitteellisessä mielessä. Esim.: "Säveltäjä X, joka on kamarimusiikkikilpailumme tilausteoksen säveltäjä, tienaa tosin leipänsä opettajana, mutta pitää itseään ennen muuta säveltäjänä; kilpailun tuomariston jäsenenä hän pyrkii arvioimaan esityksiä pianistin näkökulmasta."

Jo tämä osoittaa, ettei musiikki-instituutioita pidä kuvitella laatikkoina; pikemminkin ne ovat rykelmä toisiinsa kietoutuneita meduusoja, joilla on pieni pää ja pitkät lonkerot. Ja kun kerran eri instituutioiden henkilöstöissä voi faktisesti olla kysymys samoista ihmisistä, tulee entistä tärkeämmäksi yrittää nähdä heidät - tai ainakin selvittää voidaanko heidät nähdä - tiettyjen roolien kantajina.

\section{Aate}

Roolit ovat kuitenkin vain yksi osa instituutiota tapajärjestelmänä. Instituution ominaisuudet on johdettava niistä tavoista, joilla kaikki instituution kannalta keskeiset tehtävät hoidetaan. Tavat riippuvat käsityksistä, arvoista, normeista ja säännöistä, jotka vaikuttavat joko sellaisenaan tai rooleihin liittyvinä odotuksina. Yhdessä ne muodostavat instituution aatteen ja ideologian, so. käsityksen keskeisistä päämääristä ja keinoista sekä tätä käsitystä selittävän ja argumentoivan maailmankuvan. Ja kun on kyse musiikki-instituutiosta, yleiset ideologian ja maailmankuvan käsitteet (ks. esim. Aspelin 1970, 185-186; Manninen 1977; Puhakka 1977; Envall 1989, 113-127; Knuuttila 1989, 165-173, 187-196) voidaan täsmentää musiikki-ideologiaksi ja musiikilliseksi maailmankuvaksi (vrt. Heiniö 1984, 305). - Erityistermi, joka saattaisi sopia joi- 
denkin musiikki-insitituutioidenkin luonnehtimiseen, on jäätynyt ideologia: vanhassa laitoksessa tai organisaatiossa voivat sen organisaatiomuodot kantaa mukanaan aikoinaan elävää mutta sittemmin kivettynyttä ideologiaa, jota instituution henkilöstö ei enää sellaisenaan koe omakseen (Liedman-Olausson 1988, 18-21).

Yksinkertaisuuden vuoksi kutsun kaikkea tätä seuraavassa instituution aatteeksi. Tosin näin väljä aate-käsite merkitsee käytännössä sitä, että kahden erilaisen musiikki-instituution aatteet voivat suurelta osaltaan mennä päällekkäin - niillä on siis suurinpiirtein sama aate tai saman aatteen eri toisinto. Tämä näkemys on johdonmukainen seuraus siitä, että instituutio pyritään näkemään huomattavasti dickieläistä "taidemaailmaa" suppeampana yksikkönä. Mikäli halutaan tutkia jonkin instituution aatteen erityispiirteitä, on päähuomio näin ollen kiinnitettävä aatteen niihin momentteihin, jotka liittyvät välittömästi instituution tehtävään.

Otetaan esimerkiksi jo edellä useaan otteeseen esiintynyt nykymusiikki (nutidsmusik, Neue Musik, New Music). Carl Dahlhausin mukaan se "ei niinkään ole niiden materiaalien ja tekniikkojen varasto, joiden käyttäminen tai välttäminen ratkaisee, onko joku säveltäjä 'nykysäveltäjä' vai ei, vaan pikemminkin aate ja instituutio". Nykymusiikin väittäminen instituutioksi tarkoittaa hänen mielestään yksinkertaisesti sitä, että "jokin tietoisuuden tila, sosiaalinen ryhmittymä ja laitosten kimppu vaikuttavat yhdessä ja liittyvät toisiinsa päämääränään perustaa musiikillinen 'fait social', kuten Émile Durkheim sanoisi" (Dahlhaus 1980, 148).

Epäilemättä nykymusiikki on aate - aate jonka yhtenä sisältönä ovat konstitutiiviset säännöt, mm. juuri ne kriteerit, joiden perusteella tietynlainen aikamme musiikki on "nykymusiikkia", toisenlainen taas ei. (Esim. ISCM-valinnat osoittavat, että jokin Iannis Xenakis tai Kaija Saariaho edustavat nykymusiikkia, jokin Alfred Schnittke tai Aulis Sallinen taas eivät.) Mikään ei estä tarkastelemasta nykymusiikkia puhtaasti aatteena. Mutta sen kuvaaminen instituutiona jää puolitiehen (tai alkaa puolitiestä), mikäli aatetta ei oteta huomioon. Durkheimin "sosiaalisessa faktassa" on kyse ryhmän kollektiivisiksi ymmäretyistä uskomuksista, pyrkimyksistä ja tavoista - kiteytyneistä tai kiteytymättömistä (Durkheim 1982, 33-42). Luonnehdinta pätee kaikkiin musiikki-instituutioihin, mutta merkitsee sitä, että aate - siten kuin se ylempänä on väljästi määritelty - tulee nähdä keskeisenä osana instituutiota. 


\section{...vai mentaliteetit?}

Aate ei välttämättä ole erityisen eheä, eksplisiittinen tai täsmällisesti artikuloitu - ei varsinkaan taideinstituutioissa, joissa itse käytännön toiminnan annetaan puhua puolestaan ja joissa viime kädessä vasta ulkoinen tai sisäinen uhka (esim. identiteettikriisi) pakottaa itsereflektioon. Aatteen sijasta voitaisiinkin puhua mentaliteeteista, mikäli instituutio pohjautuu lähinnä reflektoimattomiin konventioihin.

Mentaliteeteissa on kyse tiedostamattomista tai esitietoisista - ja näin ollen luonteeltaan itsestäänselvistä - kuvitelmista, normeista, asenteista ja tavoista, jotka ovat yhteisiä suurelle kollektiiville ja joiden historialliset muutokset ovat hitaita. Ero ideologioihin, tieteisiin yms. ei koske niinkään sisältöä kuin muotoa, tajunnan tasoa. Juuri tiedostamattomalla tasolla mentaliteetit vaikuttavat yhtäältä myös aatteisiin, ideologioihin ja tieteisiin, toisaalta sosiaalisiin roolirakenteisiin sekä toiminta- ja käyttäytymismalleihin. Mentaliteetin käsite lähestyy vahvasti etnologista kulttuurikäsitettä sekä sellaisia strukturalistisia käsitteitä kuin ajatuskuvio, -rakenne ja koodi. Toisin kuin ideologiat mentaliteetit eivät ole käsitteellisiä, ne eivät siten ole suoraan luettavissa historiallisessa materiaalista vaan ne täytyy rekonstruoida. Mentaliteettihistorialle onkin ominaista se, että kirjallisten lähteiden tilalle ovat astuneet puvut, rakennukset, sisustukset, monet arkiset esineet. (Ks. Florén-Persson 1985; Virrankoski 1986; Ahtiainen 1988; Peltonen 1988; Manninen 1989, 6572.)

Mentaliteetin käsite saattaa kyllä luontua tietyntyyppisten musiikkiinstituutioiden tai joidenkin niiden osien tarkasteluun; ajatellaan esim. konsertti-instituutioita saleineen, vaatteineen, käytöstapoineen. Lähden kuitenkin siitä, että tyypillisessä länsimaisessa, sofistikoituneessa musiikki-instituutiossa aate (sanan väljässä merkityksessä) on välttämätön joskaan ei riittävä ehto. Tutkija voi rekonstruoida sen joko olemassaolevista (vaikkakin kenties katkemallisista) verbaalisista dokumenteista tai suorittamistaan haastatteluista - pitäen tulkinnoissaan luonnollisesti silmällä myös itse toimintaa. Verbaalisten dokumenttien ei tietenkään tarvitse sisältää nimenomaisia mielipiteenilmaisuja - käytännössähän ne ovat yleensä muuhun tehtävään syntyneitä ja niissä piilevä aate on luettava rivien välistä.

Mutta miten sitten erottaa aate - jonka pohjalta voi löytyä mentaliteetteja - pelkistä mentaliteeteista? Olisi outoa kutsua mentaliteeteiksi kaikkia niitä henkisiä rakenteita, jotka on pakko rekonstruoida pelkästään ei-käsitteellisistä lähteistä. (Toisin kuin monet muut instituutiot - 
esim. tiede - useimmat musiikki-instituutiot tuottavat verbaalisia tekstejä vain toissijaisesti.) Tähän näyttää kuitenkin liittyvän niin laaja probleemavyyhti, ettei siihen ole mahdollista tässä yhteydessä pysähtyä. Kertooko esim. se, että jokin instituutio - joka ei ole verbalisoinut pyrkimyksiään - suosii vain tietyn aikakauden musiikkia, jotain tämän instituution aatteesta vai pelkästään mentaliteetista? Tai: mitä jonkin säveltäjäryhmän aatteesta voi kertoa se musiikki jota he säveltävät? Ilmeisesti ei mitään, ei ainakaan suoraan vaan aina ja vain jonkin jo olemassa olevan käsitteellisen tulkinnan tai tulkintamallin välityksellä. Tämän perusteella voisi siis katsoa, että musiikki-ilmiön takana on aate vain silloin, kun se voidaan luontevasti tulkita jossakin jo olemassa olevassa, musiikkikulttuurin sisäisessä käsitteellisessä kontekstissa. Jossakin yhteydessä tällainen aate-käsitteen rajaus saattaa olla tarkoituksenmukainen, mutta instituutioiden tarkastelun kannalta se tuntuu edelleen ahtaalta.

Aatteen käsitettä määriteltäessä näyttää jäävän karkeasti ottaen kaksi vaihtoehtoa. Ensimmäisen mukaan aatteelta edellytetään käsitteellistä muotoa, joka olisi jo suhteellisen pitkälle artikuloitunut ja näin ollen tutkijan "poimittavissa". Tällainen aate-käsite implikoisi, että aatteella pitäisi olla eräänlainen sisäinen muotoutumisen ja käsitteellisen manifestoitumisen pakko, ennen kuin sitä voisi ylipäänsä aatteeksi kutsua. Toinen vaihtoehto olisi se väljempi - ja näin ollen mentaliteeteilta tilaa valtaava - aate-käsite, johon olen edellä tähdännyt. Sen mukaisesti vasta siinä tapauksessa, että instituution henkilöstöön kuuluva ei edes haastattelijan puristuksessa pysty luonnehtimaan instituution keskeisiä arvoja, normeja tai tapoja, nämä voitaisiin katsoa pelkiksi mentaliteeteiksi.

Oli miten oli, myös puutteellisesti tai jopa kokonaan julkilausumattomat ajattelun ja tuntemisen edellytykset ovat jo vanhastaan olleet aatehistorian kiinnostuksen kohteena. Lisäksi mentaliteettihistorian on katsottu luontuvan lähinnä vain sellaisten varhaisten aikakausien tutkimukseen, joilta ei ole säilynyt runsasta eikä monipuolista kirjallista lähteistöä. (Ks. Manninen 1989, 67-68.) Näin ollen pidän epätodennäköisenä, että mentaliteetin käsitteeseen olisi välttämätöntä turvautua tutkittaessa sellaisia musiikki-instituutiota joista edellä on ollut puhe.

\section{Instituutio rakennehistoriassa}

Aatehistorialla on aivan ilmeisesti avainasema musiikki-instituutioiden historiallisessa tarkastelussa. Mutta kun huomio on kiinnitettävä myös 
instituution tehtävään, materiaaliseen aparaattiin ja henkilöstöön - puhumattakaan sen varsinaisesta toiminnasta - tarvitaan monipuolisempaa tutkimusotetta. Tällainen näyttää olevan ns. rakennehistoria.

Rakennehistoriallinen näkemys syntyi 1920-luvulla ranskalaisen Annales-koulukunnan piirissä taustanaan Paul Lacomben ajatus siitä, että tapahtumahistoria (histoire événementelle) ja institutionaalinen historia (histoire institutionelle) tulisi erottaa toisistaan. Annalisteja kiinnostivat nimenomaan varsinaisia tapahtumia hitaammassa liikkeessä olevat, ts. suhteellisen pysyvät kerrostumat: sosiaaliset tekijät (le social) ja vielä hitaammin muuttuvat henkiset tekijät kuten perustavaalaatuiset uskomukset (le mental). (Huuhtanen 1973) Niinpä juuri annalistit perustivat myös mentaalihistoriallisen tutkimuksen.

Carl Dahlhausin antamien virikkeiden pohjalta rakennehistoriallinen tutkimusote on nyttemmin saavuttanut jalansijaa suomalaisessakin musiikkitieteessä. Siinähän pyritään yhdistämään teos-, tyyli-, aate-, reseptio- ja sosiaalihistorialliset lähestymistavat ja etsimään niitä rakenteita, jotka vallitsevat säveltämistä ohjaavien mallien, kuulotottumusten, esteettisten ideoiden, eettisten normien ja sosiaalisten laitosten välillä. (Ks. Dahlhaus 1977, 67 ja 205-236, Lappalainen 1989, 84.) Ehkä tämä todella tarjoaa yhden keinon luontevaan historialliseen kerrontaan, jossa näkökulmaa vaihdetaan joustavasti aina kuvattavan ajankohdan mukaan; ehkä metodinen ekletismi on terve piirre historiografiassa. Mutta kuten Dahlhaus itsekin on todennut musiikin rakennehistorian teoreettinen perustelu on kaikkea muuta kuin ongelmaton alkaen jo siitä, että rakennehistorian vaihtoehto ei musiikissa ole tapahtumahistoria vaan teoshistoria (Dahlhaus 1983).

Juuri musiikki-instituutio (erityisesti mukaan lukien siinä piilevä aate) saattaisi kuitenkin olla sellainen yksikkö, johon rakennehistorian erilaiset tarkastelutavat voitaisiin koherentilla tavalla fokusoida. Eikä tämä käsittääkseni edellytä vielä mitään kannanottoa rakenteen ontologiseen statukseen tai historiallisten ilmiöiden syy- ja seuraussuhteisiin. Näistähän näyttää ranskalaisella ja suomalaisella taholla olleen eri käsitys: Taina Huuhtanen $(1973,138)$ on todennut, että kun annalisteille rakenne oli niiden tutkittavana ajankohtana vaikuttaneiden tekijöiden kokonaisuus, jotka aiheuttavat tai tuottavat tiettyjä ilmiöitä, niin Pentti Renvallille se taas oli kokonaisuus, jonka avulla jokin menneisyyden ilmiö selittyy mielekkääksi. Renvall tarkoitti rakennekokonaisuudella sellaista "ilmiöryhmää, jonka osat eivät ole toisistaan irrallaan, vaan jonkin hallitsevan tekijän, rakenneominaisuuden, määräämässä suhteessa toisiinsa" (Renvall 1983, 335). 


\section{Valta}

Varmaankin se että instituution käsitteeseen usein liittyy negatiivisia mielteitä, johtuu olennaisesti siitä että instituutiot nähdään valtarakenteina. Valta näyttää väistämättä olevan kriittinen käsite ja vallan tiedostaminen näin ollen jo oire vallankäytön aiheuttamista ongelmista.

Tätä käsitystä tukee modernismin ideologia, jonka mukaan aidosti ajankohtainen musiikki sisältää aina kriittisen momentin eikä niin muodoin voi olla törmäämättä institutionaalisiin valtarakenteisiin. - Vrt. Adorno (1981, 145): "Musik realisiert im Musikleben, aber das Musikleben widerspricht der Musik." - Kuitenkin monet musiikkielämän kukoistusilmiöt (esim. musiikkijuhlat), joita ollaan valmiit yleisesti kiittämään, ovat aina myös tehokkaan ja tarkoituksenmukaisen vallankäytön hedelmiä. Eikä modernismin ideologiaan nojaava nykymusiikki kuulu tässä suhteessa ollenkaan taitamattomimpiin instituutioihin! (Erityisesti seuraavat kaksi sen piirteistä ovat silmiinpistäviä: Ensinnäkin se on kyennyt hankkimaan niin vahvan taloudellisen aseman ja yhteiskunnallisen statuksen, ettei sen tarvitse juurikaan piitata ulkopuolisten käsityksistä tai toiveista. Toiseksi sellaiset aikamme säveltäjät, joiden musiikki on nykymusiikkipiirien mielestä regressiivistä, voidaan sulkea instituution ulkopuolelle. Juuri tähän viitataan "militantista modernismista" puhuttaessa. - Vrt. Heiniö 1988, 7-10 ja 21-22.)

Epäilemättä siis myös musiikki-instituutioilla - tai niiden johtavilla henkilöillä - on valtaa ja auktoriteettia, jotka vaikuttavat instituution sisäiseen ja/tai ulkopuoliseen toimintaan. Tässä suhteessa erilaiset instituutiot voivat kuitenkin ratkaisevasti erota toisistaan. Ensinnäkin: kun puhutaan vallasta, sen täytäntöön panijana on aina viime kädessä henkilöinstituutio. Toiseksi: mitä selvemmin instituutio on paikallistettavissa tiettyyn organisaatioon tai laitokseen, sitä helpommin analysoitavissa ovat myös sen päätöksentekoprosessi $(\mathrm{mm}$. hallinnon kollegiaalisuus/korporatiivisuus/demokraattisuus) ja päätösten vaikutukset. Mutta tämä on vasta yksi tapa tutkia valtaa.

Muut vallan tutkimustavat ovatkin jo hankalampia. Dispositiokäsitteenä valta ei tarkoita niinkään tosiasiallista vaikutusta kuin mahdollisuutta vaikuttaa, mitä voidaan arvioida tutkimalla, missä määrin instituutiolla on hallussaan vallankäytön välineitä (rahaa, joukkotiedostusvälineitä, tuotantovälineitä jne.). Kolmas mahdollisuus on pyytää ihmisiä itse arvioimaan, kenellä on valtaa ja kenellä ei. (Eskola 1986, 114-115) Juuri tällaista 'fenomenologista' valtaa on sikäli tärkeä tarkastella, että se antaa epäilemättä oman värinsä instituution aatteelle. - Tosiasioiden 
vastaisinakin instituution henkilöstön käsitykset omasta instituutiostaan ovat kiinnostavia, mistä yhden esimerkin tarjoaa ns. suhteellisen deprivaation kokeminen: juuri silloin kun vaikutus- tai menestymismahdollisuudet instituutiossa ovat suuret, niihin ei ollakaan enää tyytyväisiä; mitä useammat ovat päässeet niistä osalliseksi, sitä itsestäänselvemmiltä ja merkityksettömämmiltä ne osallisista tuntuvat ja sitä katkerammalta maistuu osattomien kohtalo (ks. Eskola 1986, 146-147).

Merkittävää vallankäyttöä tapahtuu tietenkin myös muodollisten päätöksentekoprosessien ulkopuolella, ja näin on asianlaita jo organisaatioissa ja laitoksissa itsessään, puhumattakaan sitten niistä instituutioista jotka eivät ole organisoituneet. Voitaisiin tosin sanoa, että näissä tapauksissa ei käytetä valtaa vaan auktoriteettia. Eroa on kuvattu seuraavasti (ks. Lagerspetz 1989, 59): Jos vallan omaava taho esittää, että "Antakaa X:n tapahtua", siitä seuraa, että X todella tapahtuu. Jos taas auktoriteetin omaava taho esittää samaa, siitä seuraa vasta, että X:n pitäisi tapahtua. Auktoriteetti antaa relevantille henkilölle perusteen toimia siten, että $\mathrm{X}$ tapahtuu.

Olisi kuitenkin melko lailla arkikielen vastaista esittää, että jollakulla on auktoriteettia mutta ei valtaa. Todettavissa oleva (ts. ainakin kertaalleen käytetty ja siten osoitettu) valta - tai pitäisikö sanoa "vaikutusvalta" - on toki auktoriteetin kriteeri. Niinpä esim. poliittisen auktoriteetin on - kuten Eerik Lagerspetz toteaa - oltava efektiivistä päästäkseen ylipäätään auktoriteetiksi; poliittinen auktoriteetti onkin poliittisen vallan "eräs muoto tai pikemminkin lähde" (mts. 59). Auktoriteettia on siis tarkasteltava vallan käsitteen alla eikä vain ohessa.

Jo intuitiivisesti on selvää, että valtaa on kahta päätyyppiä: yhtäältä välitön, pakonomainen suora vaikuttaminen, toisaalta välillinen vaikuttaminen vetoamalla vallan kohteena olevan omaan harkintakykyyn, hänen rationaalisesti punnittavissaan oleviin perusteisiin. Lagerspetz esittâä nämä seuraavanlaisena diagrammana (mts. 59):

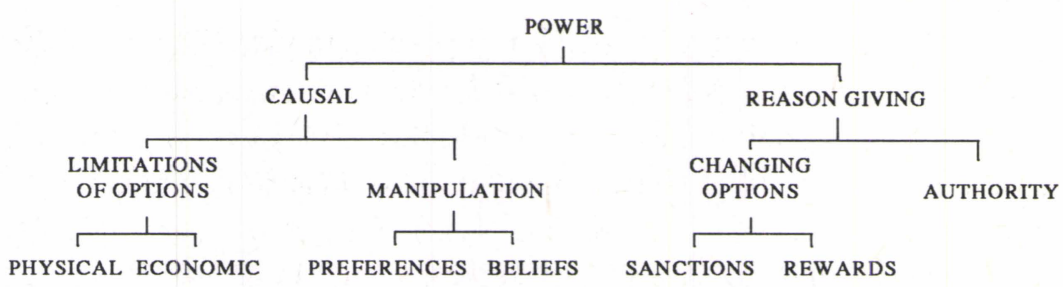


Musiikkielämästä löytyy kaikkia näistä vaikutusmuodoista - ainakin mikäli nämä katsotaan vain ideaalityypeiksi, jotka konkreettisessa vallankäyttötilanteissa sekoittuvat. Käyn kaavion läpi vasemmalta oikealle. Pitäydyn sen implikoimaan laskevaan valtahierarkiaan, jossa kahdenväliset valtasuhteet näyttävät sikäli epäsymmetrisiltä, että toisella taholla on aina ns. valtaetu. Käytännössä kyse ei kuitenkaan ole juurikaan täydellisestä vaan osittaisesta kontrollista: vallan käyttäjän on otettava huomioon vallan kohteen vastasiirto. Asetelmaa on ollut tapana analysoida peliteoreettisilla malleilla. (Ks. Eskola 1986, 112-113 ja 118-121.)

Taiteilijaan kohdistuva vallankäyttö on usein kausaalista siten, että hänen vaihtoehtonsa rajataan fyysisesti estämällä hallinnollisin päätöksin häntä tuomasta taidettaan esiin tai ekonomisesti torjumalla taiteentekemisen taloudelliset edellytykset. (Tätä ei muuta miksikään se, että kyse ei ole torjumisesta torjumisen vuoksi vaan rajallisten - ikuisesti rajallisten - resurssien kohdistamisesta "paremmille".) Edellinen valta on kuten tunnettua lähinnä välitys- ja jakeluorganisaatioiden käsissä (orkesterit, festivaalit, radio, levy-yhtiöt, kustantamot yms.), jälkimmäinen taas lukuisien suoraa tukea jakavien tahojen käsissä (yksityiset säätiöt, tekijänoikeusjärjestöt, valtiolliset ja kunnalliset toimikunnat yms.). - Näiltä osin kiinnostava - joskin jo yli kahdenkymmenen vuoden takainen - dokumentti on Suomen Musiikin Vuosikirja 1965-66: Pekka Gronowin kirjoituksen "Suomalainen musiikkipolitiikka" ohella siinä on laaja yleiskatsaus musiikkielämämme henkilöinstituutioihin.

Mieltymysten ja uskomusten manipuloinnista itse kukin löytänee niin ikään helposti esimerkkejä. Ehkä liiankin helposti, sillä demagogisena muotiterminä "manipulaatio" on varsin usein ulotettu kuvaamaan tilanteita, joissa mieltymykset ja uskomukset valitaankin auktoriteettiin nojautuen, samalla suhteellisen vapaasti harkiten. Todella manipuloitu ei juuri tule pohdiskelleeksi omia mieltymyksiään tai uskomuksiaan; hänellä ei ole siihen edellytyksiä tai riittävää intressiä. Musiikkielämän osapuolista selvimmin manipuloitavissa on yleisö, ja tämä liittyy siihen jo edellä todettuun seikkaan, ettei yleisöllä ole roolia vaan pelkkä funktio. - Kärjistäen sanoen: todellinen manipuloija tapaa paljastaa itsensä ilmoittamalla: "Nyt esitämme yleisön pyynnöstä...."

Puudiagramman oikea haara kuvaa siis valtaa, joka vaikuttaa kohteeseensa antamalla tälle rationaalisen, harkittavissa olevan perusteen tehdä vallankäyttäjän haluamat valinnat. Epäilemättä myös musiikkielämässä syntyy tilanteita, joissa palkkiot ja sanktiot ohjaavat valitsemaan tietyn vaihtoehdon. Taiteilijan kannalta tärkein institutionaalinen palkkio on kuitenkin uusi, ehkä vielä entistä parempi työtilaisuus. (Ta- 
vallaan tämä vallanmuoto antaa siis vallan kohteelle mahdollisuuden vaikuttaa itseensä kohdistuvaan kausaaliseen valtaan.) Lagerspetz katsoo, että tällainen pakottaminen - tai ehkä paremmin hillitseminen ('coercion') - ja auktoriteetin käyttö ovat sikäli samanlaisia, että ne muuttavat toiminnan perusteita. Edellinen kuitenkin vaikuttaa ensijaisiin perusteisiin, suoraan intresseihin, tekemällä jotkut vaihtoehdot vähemmän houkutteleviksi kuin toiset. Jälkimmäinen taas antaa perusteet olla nojautumatta ensisijaisiin perusteisiin. (Lagerspetz 1989, 62)

\section{... auktoriteetti ja valtaketjut}

Koska musiikki-instituutioiden olennainen osa on niissä piilevä aate, on juuri auktoriteetti niille erityisen tärkeä vallankäytön muoto. Auktoriteetti riippuu saamastaan tunnustuksesta ja vaikutuksestaan käytännön toimintaan, minkä Lagerspezt (mts. 62-63) erittelee seuraavasti:

"A is an authority in S [=tietty yhteisö] if

(1) A claims that his decisions intended to direct the actions of the members of $\mathrm{S}$ should be followed by the members of $\mathrm{S}$ because of their authoritative nature.

(2) A claims legitimacy, i.e. he claims that (1) is justified on grounds acceptable to the members of $\mathrm{S}$.

(3) The members of S do generally accept the claim expressed in (1).

(4) The members of S generally fallow the decisions of A.

(5) There are mutual beliefs in S that (3) and (4) are true.

(6) (5) is at least partial reason for (4); or

(7) while (3)-(6) are not true in respect with $A$, there is a further authority $A^{\prime}$ which authorizes A, and (3)-(6) are true in respect of $\mathrm{A}^{\prime}$."

Lagerspetzin määritelmä koskee lähinnä poliittista auktoriteettia, ja tässä yhteydessä on kiinnostavaa, sopiiko se mutatis mutandi kuvaamaan myös musiikkipoliittista auktoriteettia. Tälle käsitteelle ei kuitenkaan löydy yhtä suoralta kädeltä käytännön vastinetta. Keskeinen musiikkipoliittinen vallankäyttö kun tapahtuu lähinnä Lagerspetzin puudiagramman muilla oksilla - sehän liittyy ennen muuta organisaatioiden ja laitosten päätöksentekoon. Ei tunnu kovin luontevalta pyrkiä osoittamaan, että tämän päivän Suomessa joku tietty henkilö olisi musiikkipoliittisen auktoriteetin ruumiillistuma, jonka päätöksiä suoraan seurattaisiin. 
Mutta epäilemättä Suomessa on henkilöitä, jotka omaavat musiikkipoliittista auktoriteettia, ei niin että tämä vaikuttaisi vallankäytön kohteeseen suoraan, vaan niin että se vaikuttaa muiden vallankäyttäjien ja muiden - suorempien - vallankäytön muotojen välityksellä. Auktoriteetin valta muuttuu siis matkan varrella kausaaliseksi vallaksi, jonka tulosta auktoriteetti itse ei ole ehkä tullut edes ajatelleeksi. Valtasuhteet eivät käytännössä koskaan ole vain kahdenvälisiä, vaan ne ketjuuntuvat. Auktoriteetti on saattanut lausua pelkän arvoarvostelman, ja joku toinen vetää musiikkipoliittisen johtopäätöksen. Valta onkin usein intransitiivista eikä transitiivista (vrt. Eskola 1986, 113): se ei siis sellaisenaan, saman tyyppisinä sysäyksinä etene ketjun alusta loppuun. Tämä tekee tietenkin käytännössä vaikeaksi todeta, mihin asti valta ulottuu ja mikä varsinkin pitemmän ketjun lopulla - on muiden tekijöiden vaikutus.

Malliesimerkin tarjoaa musiikkikritiikki. Kriitikot väittävät usein, että heillä ei ole valtaa musiikkielämässä ja että he ovat riippumattomia. Kumpikaan väite ei ainakaan sellaisenaan ole uskottava.

Kriitikko ei vaikuta taiteilijaan suoraan vaan päätöksentekijöiden välityksellä. Tämän toteamiseksi riittää oikeastaan sen osoittaminen, että musiikkiarvosteluilla on hyvin näkyvä asema ja että niitä myös luetaan. Jatko on pelkästään johdonmukaista päättelyä. Olisi nimittäin lapsellista väittää arvosteluja viihdelukemistoksi, joka heti lukemisen jälkeen katoaa mielestä jälkeäkään jättämättä. (Ei viihdelukemistokaan sitäpaitsi katoa.) Kriittinen etäisyys musiikkiarvosteluihin edellyttää niin huolellista lukemista ja pohdiskelua, että tuskin päätöksentekijöillä siihen yleisesti ottaen on aikaa. Vanha vitsi "Kriitikkoon X voimme luottaa; hän erehtyy aina." on siis sikäli vailla todellisuuspohjaa. (Sinänsä juuri sana "luottaa" paljastaa, että kriitikolla on auktoriteetin valtaa.)

Kritiikin ns. riippumattomuus on selvästi valtaan liittyvä käsite: sillähän tarkoitetaan, että musiikkielämän muiden tahojen valta ei ulotu kritiikkiin. Vapaa ei toki kriitikkokaan ole: häneen kohdistuu hänen lehtensä valta. Tämä on luonteeltaan ensisijaisesti kausaalista - tarkemmin sanoen fyysistä ja ekonomista. Lehden vallassa on antaa tai olla antamatta kriitikolle valta, ja mitä suurempi lehti sitä suurempi valta sillä on annettavanaan. Se taas, vetävätkö musiikkikritiikki- tai sanomalehtiinstituutio tästä asiantilasta eettisiä johtopäätöksiä, voidaan selvittää niiden aatetta tutkimalla. (Yleistä materiaalia tarjoaisi esim. meikäläinen 80-luvun "infokratia"-keskustelu ja siinä kritisoitu pureva, pikemmin henkilöihin kuin asioihin puuttuva von oben -journalismi.)

Mikä substantiaalinen suhde musiikkiarvostelujen ja lehden yleisen toimituksellisen otteen välillä on? Tuleeko siinä esiin lehden manipula- 
tiivinen tai auktoriteettivalta kritiikkiin nähden? Näiden kysymysten selvittely edellyttäisi, että tarkastelun kohteeksi nostetaan myös musiikkitoimituksen (sekä ylipäänsä kulttuuritoimituksen) muut, pikemmin tiedottavaan kuin arvottavaan tehtävään asetetut tekstit. On vaikea sanoa, missä määrin sanomalehtien musiikillinen auktoriteetti vaikuttaa juuri näistä teksteistä, missä määrin taas arvosteluista käsin. Kirjoittajathan ovat olennaisilta osin samoja, eivätkä he juuri vedä rajaa tiedonvälityksen ja mielipiteenilmaisun välille (vrt. Heiniö 1985b, 49). Ilmeisesti onkin niin, että jos musiikkikritiikki-instituutiota halutaan tutkia sellaisena kuin se Suomessa on ilmennyt 50-luvun lopulta alkaen, musiikkitoimittajien muitakin tekstejä on pidettävä silmällä.

\section{Traditio}

Arkikielessä auktoriteetin käsite saa usein sellaisia vivahteita, jotka tekevät auktoriteetista suoraan kausaalisen vallan käyttäjän. Valistusajan perinteenä elää edelleen käsitys auktoriteetista eräänlaisen manipulaation - auktoriteettiuskon - lähteenä, ennakkoluulojen pönkittäjänä. Tällaisena se muodostaa selvän vastakohdan yksilön omalle järjelle ja vapaalle harkintakyvylle - vastakohdan jota Hans Georg Gadamer pyrkii purkamaan kuuluisassa "auktoriteetin ja tradition rehabilaatiossaan" (1975, 261-264). Gadamerin mukaan auktoriteetin seuraaminen ei merkitse alistumista eikä järjen abdikaatiota vaan tiedon ja tunnustuksen aktia, ts. sen myöntämistä että joku tietää paremmin kuin minä. Auktoriteetti nähdään siis mielummin totuuden kuin ennakkoluulojen lähteenä.

Gadamerin ajatus on siinä mielessä triviaali, että jokaisessa valintatilanteessa on pakko hyväksyä koko joukko seikkoja annettuna, kaikkea ei voi yhtä aikaa kyseenalaistaa. Lisäksi hänen auktoriteettikäsitteensä on ymmärrettävä sitä vasten, että keskeisin auktoriteetin muoto hänelle on traditio. Edellä auktoriteettia on kuitenkin tarkasteltu yhtenä vallan muotona, ja instituution valtaa käyttävät aina yksilöt - niissä rooleissa jotka instituutio on määritellyt. Vallankäyttäjät voivat tietenkin nojautua traditioon, mutta koko vallan käsite väljähtyisi, jos sanottaisiin että traditio käyttää valtaa.

Mutta mikä sitten on tradition olemus? Gadamerin traditiokäsitys tuntuu kyllä luontevalta niiden musiikki-instituutioiden kohdalla, joiden jatkuvuus perustuu tietoisesti strukturoituun ja organisoituun traditionsiirtoon jossa myös voidaan reagoida muuttuviin olosuhteisiin (esim. musiikkioppilaitokset). Aivan toisenlaista traditiokäsitystä tarjoavat 
esim. Theodor W. Adorno ja Carl Dahlhaus: elävä traditio ei pohdi perusteitaan tai oikeutustaan, joten tradition itsereflektio on oire sen murtumisesta (Adorno 1972, 124; Dahlhaus 1973, 177-178). Tältä kannalta katsoen tradition itsereflektiossa on kyse aina jo tradition apologiasta (ks. Heiniö 1984, 11-12). Tämä näkemys auttaa kyllä hahmottamaan modernismin ja traditionalismin suhdetta luovassa säveltaiteessa, mutta sen soveltuvuus niihin instituutioihin nähden, joissa uuden ja vanhan vastakkainasettelu ei ole yhtä ilmeistä, jää tapaus tapaukselta punnittavaksi. - Tradition näkeminen yhtäältä tunnustettuna auktoriteettina ja toisaalta tiedostamattona itsestäänselvyytenä on analoginen jaottelulle aate/mentaliteetit.

Instituution konstitutiivisina tekijöinä olen pitänyt tehtävää, aatetta, materiaalista aparaattia ja henkilöstöä. On helppo nähdä, että traditiossa siirtyvät eteenpäin lähinnä kaksi ensimmäistä. Instituution keskeinen piirre, pysyvyys ja jatkuvuus, tulee esiin siis siinä, että nimenomaan tehtävä ja aate pysyvät vaikka henkilöstö (ja mahdollisesti myös materiaalinen aparaatti) vaihtuisi. Jos tehtävä ja aate vaihtuvat - ja kun toinen muuttuu, muuttuu toinenkin - , niin koko instituutio vaihtuu.

\section{Lähteet}

Adorno, Theodor

1972 Tradition. Dissonanzen. 5. Auflage. Göttingen

1981 Einleitung in die Musiksoziologie. Zwölf theoretische

Vorlesungen. 4. Auflage. Baden Baden

Ahtiainen, Pekka

1988 Nykyaika, historia ja mentaliteetti. Historiallinen aikakauskirja 1988:4

Allardt, Erik

1983 Sosiologia I. Juva

Asp, Erkki - Peltonen, Matti

1980 Työnsosiologia. Helsinki

Aspelin, Gunnar

1970 Tankehistoriens problem. Stockholm

Dahlhaus, Carl

1973 Traditionzerfall im 19. und 20. Jahrhundert. Studien zur Tradition in der Musik. Kurt von Fischer zum 60. 
Geburtstag. Hrg. von H. H. Eggebrecht und Max Lütolf. München

1977 Grundlagen der Musikgeschichte. Köln

1980 Nykymusiikki tänään. Saksankielisestä käsikirjoituksesta Neue Musik heute suom. Mikko Heiniö. Musiikki 1980:3

1983 Vorwort. Texte zur Musiksoziologie. Hrsg. von Tibor Kneif. 2. Auflage 1983. Laaber-Verlag

Dickie, George

1974 Art and the Aesthetic. An Institutional Analysis. Cornell University Press

1987 Paluu taideteoriaan.Taide ja filosofia. Toim. Markus

Lammenranta ja Arto Haapala. Helsinki

Douglas, Mary

1987 How Institutions Think. Syracuse University Press Durkheim, Émile

1982 Sosiologian metodisäännöt. Ranskankielisestä alkuteoksesta Les règles de la méthode sociologique, 19. Envall, Markku

painos 1977 suom. Seppo Randell. Helsinki

1989 Kirjallisuus ja maailmankuva. Manninen, Juha - Envall,

Markku - Knuuttila, Seppo, Maailmankuva kulttuurin

kokonaisuudessa. Jyväskylä

Eskola, Antti

1986 Sosiaalipsykologia. 9., muuttumaton painos. Helsinki Florén, Anders - Persson, Mats

1985 Mentalitetshistoria och mentalitetsbegreppet. Lychnos

(Lärdomshistoriska Samfundets Årsbok) 1985

Gadamer, Hans Georg

1975 Wahrheit und Methode. Grundzüge einer philosophischen

Hermeneutik. 4. Auflage. Tübingen

Gronow, Pekka

1966 Suomalainen musiikkipolitiikka. Suomen Musiikin

Vuosikirja 1965-66

Haapala, Arto

1989 What is a Work of Litterature? Acta Philosophica

Fennica Vol. 46. Helsinki

Heiniö, Mikko

1984 Innovaation ja tradition idea. Näkökulma aikamme suomalaisten säveltäjien musiikkifilosofiaan. Acta Musicologica Fennica 14. Helsinki 
1985a Taide- ja populäärimusiikki. [Suom. versio Alvar Aalto symposiumissa Jyväskylässä 1985 pidetystä esitelmästä. ] Julkaistu: Etnomusikologian vuosikirja 1986. Toim. Vesa Kurkela ja Erkki Pekkilä. Jyväskylä 1987

1985b Näkökulmia suomalaisen musiikkikritiikin tutkimukseen. [Esitelmä Suomen Arvostelijain Liiton kriitikkopäivillä Helsingissä 13.4.1985.] Julkaistu: Etnomusikologian vuosikirja 1987-88. Toim. Erkki Pekkilä ja Vesa Kurkela. Jyväskylä 1988

1988 Lastenkamarikonserteista pluralismiin. Postmoderneja piirteitä uudessa suomalaisessa musiikissa. [ = Musiikki 1-2/1988] Helsinki

Huuhtanen, Taina

1973 Rakennehistoria - Tapahtumahistoria. Ranskalainen

"Annales"-koulukunta strukturalistisen

historiantutkimuksen edustajana. Historiallinen aikakauskirja 2/1973

Jones, Kathleen - Fowles, A. J.

1984 Ideas on Institutions. Analysing the literature on longterm care and custody. London

Kneif, Tibor

1966 Der Gegenstand der musiksoziologischer Erkenntnis.

Texte zur Musiksoziologie. Hrsg. von Tibor Kneif. 2.

Auflage 1983. Laaber-Verlag

1975 Musiksoziologie. 2. Auflage. Köln

Knuuttila, Seppo

1989 Kansanomainen maailmankuva. Manninen, Juha - Envall, Markku - Knuuttila, Seppo, Maailmankuva kulttuurin kokonaisuudessa. Jyväskylä

Lagerspetz, Eerik

1989 A Conventionalist Theory of Institutions. Acta philosophica fennica Vol. 44. Helsinki

Lappalainen, Seija

1989 Suomen musiikinhistorian tutkimusprojektista. Musiikkitiede 1/1989

Liedman, Sven-Eric

1987 Form och innehåll. Arachne, texter från institutionen för idé- och lärdomshistoria vid Göteborgs universitet, $\mathrm{nr} 2$.

Liedman, Sven-Eric - Olausson, Lennart (toim.) 
1988 Ideologi och institution. Om forskning och högre

Lindblom, Paul

$$
\text { utbildning 1880-2000. Helsingborg }
$$

1981 Det handlar om musikpolitik. Stockholm Manninen, Juha

1977 Maailmankuvat maailman ja sen muutoksen heijastajina. Maailmankuvan muutos tutkimuksen kohteena. Toim.

Matti Kuusi, Risto Alapuro ja Matti Klinge. Keuruu

1989 Tiede, maailmakuva, kulttuuri. Manninen, Juha - Envall, Markku - Knuuttila, Seppo, Maailmankuva kulttuurin kokonaisuudessa. Jyväskylä

Mueller, John H.,

1963 A Sociological Approach to Musical Behavior Ethnomusicology VII, 1963

NSSK

1977 Nykysuomen sivistysanakirja. SKS. Helsinki Peltonen, Matti

1988 Johtolankoja ja tiheää kirjausta. Mitä uutta mentaliteettien historia on tuomassa? Historiallinen aikakauskirja 1988:4 Puhakka, Kaisa

1977 Maailmankuvien tutkimuksesta ja rakentamisesta.

Maailmankuvan muutos tutkimuksen kohteena. Toim.

Matti Kuusi, Risto Alapuro ja Matti Klinge. Keuruu

Renvall, Pentti

1983 Nykyajan historiantutkimus. 2. painos. Juva Robbins, Richard H.

1973 Culture and Behavior. Handbook of Social and Cultural Anthropology. Ed. by John J. Honigman. Chicago

Searle, John

1974 Speech Acts. Cambridge University Press

Silbermann, Alphons

1957 Wovon lebt die Musik. Regensburg

Stefani, Gino

1985 Musiikillinen kompetenssi. Italiankielisestä alkuteoksesta

La Competenza Musicale suom. Heikki Nylund.

Jyväskylän yliopiston musiikkitieteen laitoksen

julkaisusarja A, no 3 .

Säätelä, Simo

1986 Taidemaailma: taiteen kehykset ja paradigmat. Synteesi $1 / 1986$ 
Wartofsky, Marx W.

1980 Art, Artworlds, and Ideology. The Journal of Aesthetics and Art Criticism 1980, Vol. XXXVIII

Wieand, Jeffrey

1981 Can There Be an Institutional Theory of Art. The Journal of Aesthetics and Art Criticism 1981, Vol. XXXIX

Wiora, Walter

1962 Die musikalischen Gattungen und ihr sozialer

Hintergrund. Texte zur Musiksoziologie. Hrsg. von

Tibor Kneif. 2. Auflage 1983. Laaber-Verlag

Virrankoski, Pentti

1986 Mentaliteettikäsite historiassa. Historiallinen arkisto 88

Aiheeseen liittyvistä kommenteista ja keskusteluista parhaat kiitokset dos. Arto Haapalalle ja yht. tri Eerik Lagerspetzille.

Summary:

\section{IN THE POWER OF IDEAS.}

Viewpoints of the concept of 'Music Institution'

From the viewpoint of sociology an institution is made up of established norms and rôles plus customs which are presupposed by those norms and rôles and which have a social function. In everyday language institutions seem to be, nevertheless, concrete establishments or organisations whose position can be exactly defined in time and place. This apprehension has obviously made its way into the historiography of music as well.

But a music institution is always a system of practices and in addition to that it can be a certain social establishment. When emphasizing the former aspect we are talking about the function and the ideas of the institution, and when emphasizing the latter aspect we are talking about its material apparatus and personnel. In the same way we can make the difference between an action-institution and a person-institution: the former needs - in order to be able to function - a certain kind of material 
apparatus and personnel, but the latter needs a certain apparatus and personnel.

The western concert institution is a comprehensive action-institution, which presupposes the existence of many such person-institutions as e.g. the local philharmonic orchestras and concert societies. (In these institutions we can find again various smaller action-institutions - e.g. the use of tailcoat -, but in this context it would, nevertheless, be appropriate to simply call them social practices.)

It is a typical feature for many person-institutions that one is partially or almost totally within the other. New Music encompasses abundance of person-institutions which serve its function and ideas. It is an institution of institutions in the same way as folk (or traditional) music, 'light' music and 'serious' music. 'Light' music and 'serious' music define each other: the one is what the other is not. The most essential difference between them is not a musical but an institutional one: when looking at their production, distribution and reception, you'll find a deep breach between them going through the whole society. It would be worth while analysizing also less comprehensive genres such as the opera and the symphony in purely institutional terms.

According to George Dickie the 'art world' is a frame for the artistic work. In the analyze of institutions (even though Dickie is mistaken when calling the 'art world' an institution) the frame can be seen at least as a heuristic model, and correspondingly the whole institution can be seen at least as an adequate angle to very many kinds of musical phenomenona. Even if the (slowly changing) frame can be abstracted from the (fast changing) actual actions, it could be elucidating to scrutinize it as a part of the actions. It is not substantially the concert hall which makes the concert possible, but it is the concert which makes the concert hall possible.

As all institutions the music institution has its constitutive and regulative rules. With the former it is defining its function and goals, its nature and criteria for membership. With the latter it is prescribing what should be done and what should not. Most of the rules are, however, implicit: they are included in the institutions' mutual beliefs, they form the normative aspect of the system of beliefs.

The rules which govern the special tasks inside the institution are concentrated on the rôles. In the institutions of Western art music these rôles have developed into professional rôles and identities. Correspondingly, the original rôle of the audience has narrowed down to a mere function: the audience can give only a categorical feed-back, take it or 
leave it. Most of the professionals are working in the circle of several institutions. Therefore their tasks, professions, titles and rôles easily get tangled up, practically and conceptually.

A central part of the institution is its ideas - a system constituted of values, norms, beliefs and rules. The ideas are not necessarily explicit or clearly articulated, and therefore they cannot always be found directly in verbal documents but have to be reconstructed. Despite of that there's no need to substitute the concept of mentality for the concept of idea, unless you will take the institutional study so far back into the past that you cannot find any verbal documents whatssoever. The same French school - 'Annales' - brought forth an other concept, which seems to fit better to the historical study of institutions: the historical structure. The institution might be a particulary suitable unit, to which the different approaches of structural history (examinations of musical works, styles, compositional techniques, ideas, audience response, social institutes and so forth) could be focused.

The power over people inside or outside the institution is causal or reason giving (see the diagram on page 25). In all music institutions an important form of power is the authority. The power relations are, however, never only bilateral but always chainlike. E.g. the music criticism is an action-institution, which, on the one hand, falls into the causal power of an outside person-institution, namely the newspaper, but which, on the other, has an authority over various person-institutions in music life. These music institutions (or their decision makers) have then the causal power (physical or economic), which finally affects the musicians.

The age of enlightenment saw authority as a kind of manipulative power. Hans Georg Gadamer in his famous 'rehabilation of authority and tradition' claims that, to follow an authority does not mean any abdication of reason but an act of knowledge and acknowledgment. For him the most important form of authority is tradition. A totally opposite definition of tradition has been proposed by Theodor W. Adorno and Carl Dahlhaus: a living tradition is self evident, and so it doesn't reflect its own grounds or legitimacy - or if it does it's already breaking down. This view helps to explain the opposition of modernism and traditionalism in the productive work of composers, but may it be that Gadamers' concept of tradition serves better the studies of such slowly changing institutions as music education.

The constitutive factors of the music institution are the function, the ideas, the material apparatus and the personnel. The importance of the 
first two becomes evident in the very fact, that they are transmitted by the tradition when the personnel (and the material apparatus perhaps too) is changing. 